УДК 621.762

Цигода В.В., Кристич Ю.В., Петровський В.Я.

Інститут проблем матеріалознавства НАН України, м. Київ

\title{
ЗАСТОСУВАННЯ ТЕРМОЕЛЕКТРИЧНИХ ПЕРЕТВОРЮВАЧІВ НА ОСНОВІ ТУГОПЛАВКИХ БЕЗКИСНЕВИХ СПОЛУК ДЛЯ ВИМІРЮВАННЯ ТЕМПЕРАТУРИ АГРЕСИВНИХ СЕРЕДОВИЩ
}

У роботі вперше показана можливість використання термоелектричних перетворювачів на основі тугоплавких безкисневих сполук для вимірювання температури агресивних середовищ, досліджено в ході експерименту відтворюваність функціонального параметру термо-е.р.с. термоелектричного перетворювача. В ході досліджень використовувалися бінарні системи WC-SIALON/caжа-SIALON, TiB $2^{-}$ SIALON/cажа-SIALON, ZrC-SIALON/B ${ }_{4} C$-SIALON, TaN-SIALON/вуглецеве волокно. Встановлено, щуо при використанні композитних матеріалів можливий ефект термокомпенсаиї̈, який проявлясться в тому, щуо матеріали WC-SIALON/caжа-SIALON проявляють в діапазоні температур до $250{ }^{\circ}$ С від 'ємне значення термо-е.р.с. за рахунок значної величини від'ємного значення домішки з негативним значенням коефіцієнта термо-е.р.с. Доведено, що використання керамічних композитів ZrC-SIALON/B ${ }_{4} C-S I A L O N$ має переваги у створенні високоефективних термоелектричних перетворювачів, в яких слабо відбуваються прочеси термокомпенсаиії. На жаль, керамічні перетворювачі мають певні недоліки, до основних недоліків слід віднести велику інерційність, щчо проявлясться у тому, що термопари не відчувають пікових змін температури.

В работе впервые показана возможность использования термоэлектрических преобразователей на основе тугоплавких бескислородных соединений для измерения температуры агрессивных сред, исследовано в проиессе эксперимента воспроизводимость функционального параметра термо-э.д.с. термоэлектрического преобразователя. В ходе эксперимента использовались бинарные системь WCSIALON/caжа-SIALON, TiB ${ }_{2}-S I A L O N / c a ж a-S I A L O N, \quad Z r C-S I A L O N / B_{4} C-S I A L O N, \quad T a N-$ SIALON/углеродное волокно. Установлено, что при использовании композиционных материалов возможен эффект термокомпенсации, который проявляется в том, что материаль WC-SIALON/сажа-SIALON имеют в диапазоне температур до $250{ }^{\circ} \mathrm{C}$ отрицательное значение термо-э.д.с. за счет больщой величины отрицательного значения примеси с негативным значеним коэфициента термо-э.д.с. Доказано, что использование керамических ZrC-SIALON/B ${ }_{4} C-S I A L O N$ имеет преимущества при создании 
высокоэффективных термоэлектрических преобразователей, в которых слабо происходят процессы термокомпенсации. К сожаленью, керамические преобразователи имеют некоторые недостатки, к которым следует отнести больщую инерционность, которая проявляется в том, что термопары не ощущают пиковых изменений температуры.

In the work the possibility of use of thermoelectric transducers based on the refractory oxygen-free compounds for measuring the temperature of aggressive environments is represented; also the reproducibility of functional parameter of thermo-electromotive force of the thermoelectric transducer is investigated for the first time. In the course of research, the binary systems WC-SIALON/soot-SIALON, TiB $B_{2}$-SIALON/soot-SIALON, ZrC-SIALON/B ${ }_{4} C$ SIALON, TaN-SIALON/carbon fibre were used. It is determined that under the use of composite materials the effect of thermal compensation is possible, which manifests itself in the fact that materials WC-SIALON/soot-SIALON in the temperature range up to $250{ }^{\circ} \mathrm{C}$ show a negative value of thermo-electromotive force due to the large negative value of admixtures with negative coefficient of thermo- electromotive force. It is proven that the use of ceramic composites $\mathrm{ZrC}$ SIALON/B ${ }_{4} C$-SIALON gives the advantages for creation of highly efficient thermoelectric transducers, in which the processes pass poorly. Unfortunately, ceramic transducers have some disadvantages, and the main of them is the large inertia, which is shown that the thermocouples are insensitive to the peak changes of temperature.

\section{Вступ}

Інтенсифікація технологічних процесів у хімії, металургії, енергетиці та інших галузях промисловості тісно пов'язана з підвищенням робочих температур і створенням нових високотемпературних процесів у поєднанні з їх автоматизацією. Вирішити дані задачі неможливо без точних і швидкодіючих датчиків температури. У цих процесах використовуються металеві або напівпровідникові термоелектричні перетворювачі, що не можуть працювати в агресивних середовищах, до яких відносять розплавлені метали, солі, шлаки, різноманітні газові середовища (окислювальні, відновлювальні, нейтральні). Тому свого часу почали розробляти термоелектричні перетворювачі на основі тугоплавких безкисневих сполук [1]. Проте в цій роботі вони не ізолювалися від оточуючого середовища, що суттєво спотворювало результати вимірювань.

У світі ведуться роботи по розробці нових термоелектричних перетворювачів 3 високою ефективністю. Проте ці роботи сфокусовані на використанні наступних матеріалів: халькогеніди вісмуту $\left(\mathrm{Bi}_{2} \mathrm{Te}_{3}\right.$ та $\left.\mathrm{Bi}_{2} \mathrm{Se}_{3}\right)$, телурид свинцю (PbTe), групи сполук магнію, термоелектричні оксиди (титанат стронцію, оксид стронцію), сплави Half Heusler 
$(\mathrm{MNiSn}(\mathrm{M}=\mathrm{Ti}, \mathrm{Zr}))$ [2, 3, 4, 5]. Дані матеріали мають певні недоліки, основні з них: наявність точки Кюрі і неможливість їх використання при температурі вище $300{ }^{\circ} \mathrm{C}$.

Суттєвий прогрес у створенні суцільно-керамічних функціональних приладів був досягнутий розробкою шаруватої технології отримання функціональних приладів, а саме: суцільно-керамічних нагрівачів для роботи в агресивних середовищах [6]. Використовуючи цей принцип, можна конструювати термоелектричні датчики, в якості резистивних шарів електричного нагрівача доцільно використовувати матеріали з високим рівнем термоелектричних властивостей [1]. У такому випадку термоелектрична контактна точка захищена від агресивного середовища шаром теплопровідної термостійкої ізоляції, здатної працювати в агресивних середовищах до $1400{ }^{\circ} \mathrm{C}$.

Метою даної роботи $є$ створення термоелектричного перетворювача із застосуванням шаруватої технології та дослідження відтворюваності функціонального параметру термо-е.р.с. термоелектричного перетворювача на базі безкисневих тугоплавких сполук.

\section{Матеріали і методи}

Використовували промислові порошки нітриду кремнію $\beta-\mathrm{Si}_{3} \mathrm{~N}_{4}$ (Бакинського заводу порошкової металургії, Азербайджан) i $\alpha-\mathrm{Si}_{3} \mathrm{~N}_{4}$ (H.C. Starck Inc., Німеччина); нітридів і карбідів перехідних металів: $\mathrm{TaN}, \mathrm{TiB}_{2}, \mathrm{ZrC}$ (Донецького заводу хімічних реактивів, Україна), В 4 C (IПМ НАН України), $\mathrm{SiC}$ (Запорізького абразивного комбінату, Україна), TaN, WC (H.C. Starck Inc., Німеччина).

Гомогенізація і розмол шихти здійснювалися в планетарному млині типу Fritsch (барабан і кулі $\mathrm{Si}_{3} \mathrm{~N}_{4}$ ) протягом 40 хв. в етиловому спирті. Концентрація провідника фази включення в композиційних термоелектродах становила $11 \%, 15 \%, 30 \%$ та $35 \%$.

Заготовки зразків для синтезу збиралися за методикою, яку описано в $[7,8]$. Автором був розроблений оригінальний спосіб організації макроструктури градієнтного композиту, згідно з яким в еластичних товстих керамічних аркушах (товщина 0,9-1,8 мм) 3 шихти для отримання термостійкого ізоляційного матеріалу методом штампування вирубуються отвори (порожнини) (рис. 1), в які потім щільно вкладаються попередньо вироблені деталі. В якості біндера використовувалася карбоксиметилцеллюлоза. Така керамічна збірка і являє собою заготовку функціонального градієнтного композиту, яка після температурної обробки (спікання) перетвориться на суцільно керамічний функціональний елемент.

Виходячи із сучасних уявлень про термоелектричні явища в двокомпонентних композитах [9], пристрій не повинен бути виготовлений 3 одного термоелектричного матеріалу. Може бути створена бінарна композитна система, проте ії властивості будуть залежати від концентрації термоелектричного матеріалу. 


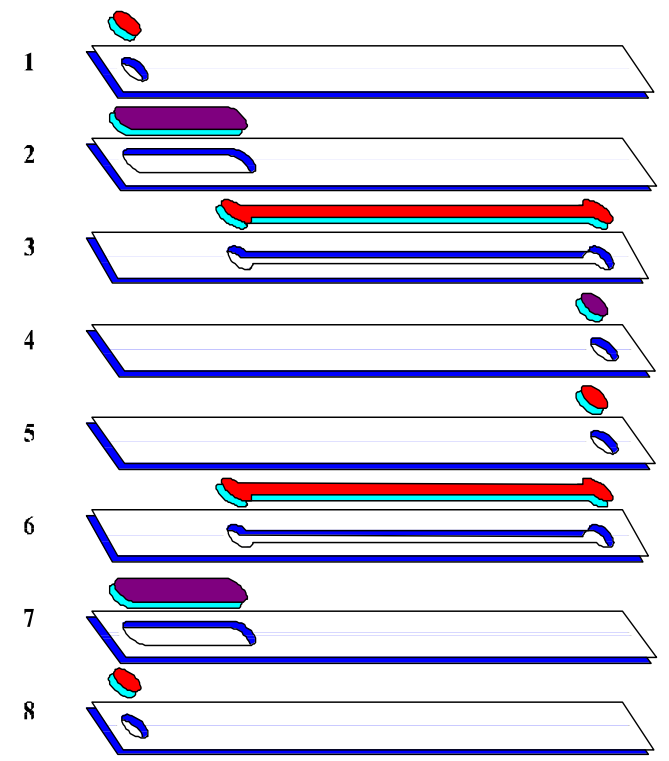

Рис. 1. Структурна схема градієнтного композиту: 1,8 - контакти; $2,4,5,7$ - зони струмопроводу; 3,6 - резистивні матеріали активної зони

Сирі заготовки шарів після формувань мали щільність 54\% - 74\% від теоретичної залежно від способу отримання стрічок. Результати заготовки зразків показані на рис. 2.
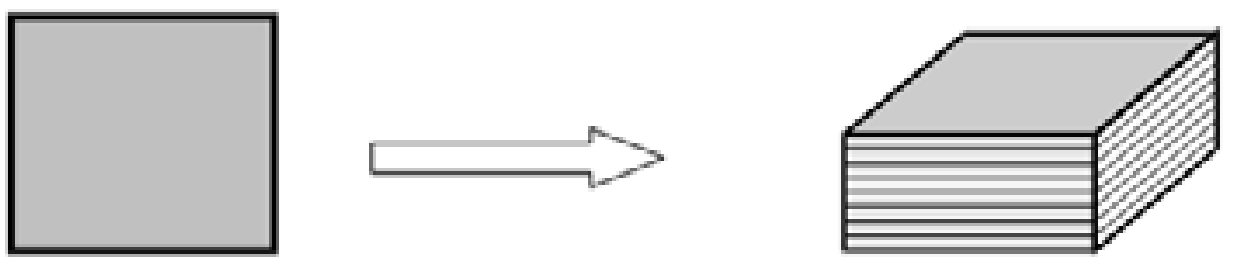

Рис. 2. Збірка заготовок зразків

Виходячи 3 термоелектричного моделювання Скала, найбільш ефективними термоелектричними перетворювачами можна вважати керамічні композити, що відрізняються за величиною теплопровідності. Дослідженнями термоелектричних властивостей тугоплавких безкисневих сполук доведено, що найбільш негативне значення коефіцієнта термо-е.p.c. мають матеріали $\mathrm{WC}, \mathrm{TiB}_{2}, \mathrm{ZrC}, \mathrm{TaN}$, а позитивне - $\mathrm{B}_{4} \mathrm{C}$, вуглецеве волокно, сажа [1]. Виходячи $з$ наведеної вище інформації, для дослідження використовували термоелектричні перетворювачі, склад яких наведений у таблиці 1. У якості корпусу використовували SIALON, який добре себе зарекомендував [6]. У таблиці

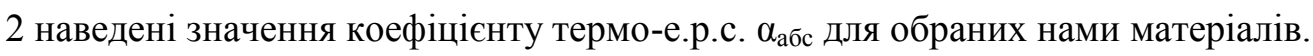


Таблиця 1.

Шарувато-градієнтні термопари, виготовлені для вимірювання значень термо-е.p.c.

\begin{tabular}{|c|c|c|}
\hline Назва термопари & Склад гілки А & Склад гілки Б \\
\hline $31-4(1)$ & $\mathrm{WC}($ об $15 \%)-\mathrm{SIALON}$ & Сажа (об 20\%)- SIALON \\
\hline $30-6(2)$ & $\mathrm{TiB}_{2}($ об $30 \%)-\mathrm{SIALON}$ & Сажа (об 20\%)- SIALON \\
\hline $34-8(3)$ & $\mathrm{ZrC}(\mathrm{O}$ (11\%)-SIALON & $\mathrm{B}_{4} \mathrm{C}($ об 40\%) - SIALON \\
\hline $30-3(4)$ & $\mathrm{TaN}($ об $35 \%)-\mathrm{SIALON}$ & Вуглецеве волокно \\
\hline
\end{tabular}

Таблиця 2.

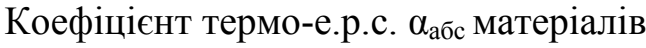

\begin{tabular}{|c|c|c|}
\hline Матеріал & Коефіцієнт термо-е.р.с. $\alpha_{\text {абс, мкВ/град }}$ Посилання \\
\cline { 1 - 2 } $\mathrm{WC}$ & $-23,3$ & \multirow{2}{*}[10]{} \\
\cline { 1 - 2 } $\mathrm{TiB}_{2}$ & $-5,1$ & \\
\hline $\mathrm{ZrC}$ & $-11,3$ & {$[11]$} \\
\hline $\mathrm{TaN}$ & $+80,0$ & {$[12]$} \\
\hline $\mathrm{B}_{4} \mathrm{C}$ & $+14,0$ & {$[13]$} \\
\hline
\end{tabular}

Величина термо-е.р.с. використовуваних матеріалів знімалася мідними дротами, які були затиснуті механічним способом на клемах вихідного сигналу. У процесі проведення експерименту основний провід охолоджувався у воді для того, щоб його температура була близько $20{ }^{\circ} \mathrm{C}$. Експерименти при температурі нижче $200{ }^{\circ} \mathrm{C}$ проводили у ванні 3 маслом, а дослідження при температурі нижче $1300{ }^{\circ} \mathrm{C}$ провели в печі з нагрівачем SiC.

Температура під час експерименту вимірювалася програмованим електронним тестером 3 похибкою 0,2\%. Температуру масла вимірювали платиновим резистором, а температуру печі з нагрівачем $\mathrm{SiC}$ - термопарою PtRh10-Pt.

Два температурні сигнали вимірювалися заводськими термопарами, і один 3 сигналів одночасно записувався в комп'ютер. Усі сигнали вимірювали 1 раз на секунду. На рис. 3 показаний вигляд панелі для запису даних у комп’ютер.

Перевірку відтворюваності величини термо-е.р.с. шарувато-градієнтних термопар проводили при циклічному нагріванні. Збільшення швидкості нагрівання печі підтримувалося в районі 4 град/хв., 3 точністю $\pm 0,2 \%$. Температура печі контролювалася паралельно платиново-платинородієвою термопарою. Сигнали від еталонної термопари і шарувато-градієнтної термопари реєструвалися за допомогою спеціальної програми та комп'ютера з інтервалом часу 1 с. 


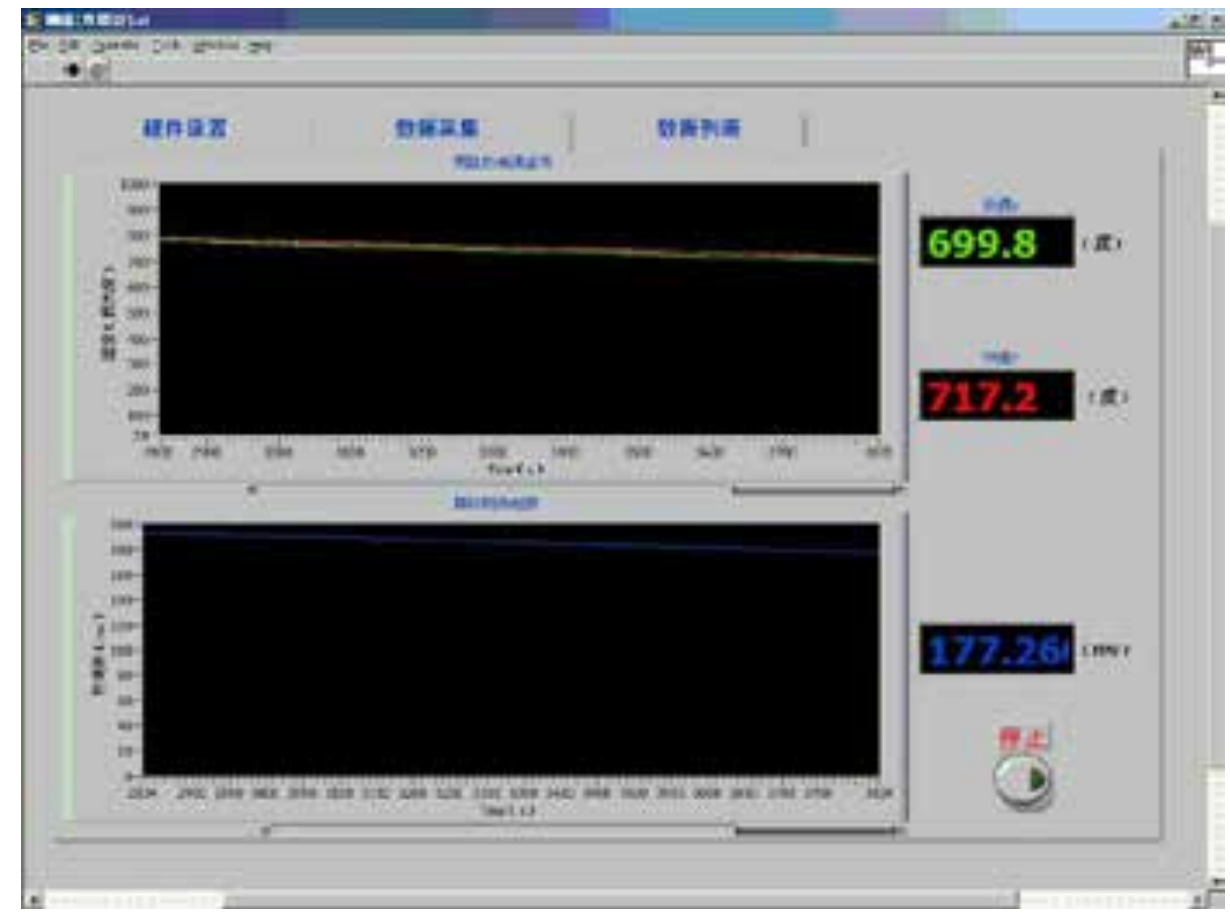

Рис.3. Контрольна панель для запису даних

\section{Результати експериментів та їх обговорення}

При проектуванні термопар за методикою шарувато-градієнтної технології важливим $є$ визначення концентрації термоелектричної добавки в бікомпонентній системі кожної з функціональних зон елементу. Відома $[14,15]$ нелінійна залежність термо-е.р.с. $\mathrm{B}_{4} \mathrm{C}$ від концентрації, тому перш за все необхідно визначитися 3 концентрацією добавки. Матеріалів 3 позитивним значенням коефіцієнту термо-е.р.с. значно менше, ніж 3 негативним його значенням (сажа, вуглецеві волокна, а також композиційні матеріали 3 $\mathrm{B}_{4} \mathrm{C}$ ). Причому $\mathrm{B}_{4} \mathrm{C}$ відрізняється набагато більшою величиною коефіцієнта термо-е.p.c. (див. табл. 2), але набагато гірше ущільнюється в технологічному процесі. У якості матеріалів з від'ємним значенням термо-е.р.с. були вибрані ті з них, які в монолітному стані мають значення коефіцієнта термо-е.р.с. від - $2 \div(-5)$ мкВ/град $\left(\mathrm{TaN}, \mathrm{TiB}_{2}\right)$ до 11,33 мкВ/град ( $\mathrm{ZrC}$ ) та - 23,3 мкВ/град (WC). Позитивна гілка була виготовлена із нанопорошку вуглецю з коефіцієнтом термо-е.p.c. +14 мкВ/град, сажі (+ 4 мкВ/град) та композитного матеріалу $\mathrm{B}_{4} \mathrm{C}\left(+80{ }^{\circ} \mathrm{C}\right)$. Проте дані про порошок вуглецю вивчалися при негативних температурах. Даних про область високих температур немає, оскільки на повітрі вуглець окислюється і випаровується у вигляді газу [16]. Шарувата технологія забезпечує ізолювання вуглецю від оточуючої атмосфери, тому він може бути використаний при високих температурах.

На рис. 4 приведено порівняння функціональних приладів 3 використанням у вигляді позитивної гілки композиту (сажа 20 об. \% - SIALON), а позитивна гілка виконана 3 матеріалів (WC 15 об. \% - SIALON) (термопара 31-4, таблиця 1) та ( $\mathrm{TiB}_{2} 30$ об. \% - 
SIALON) (термопара 30-6, таблиця 1), які відрізнялися значенням коефіцієнту термо-е.р.с. в 4 рази (див. таблиця 2).

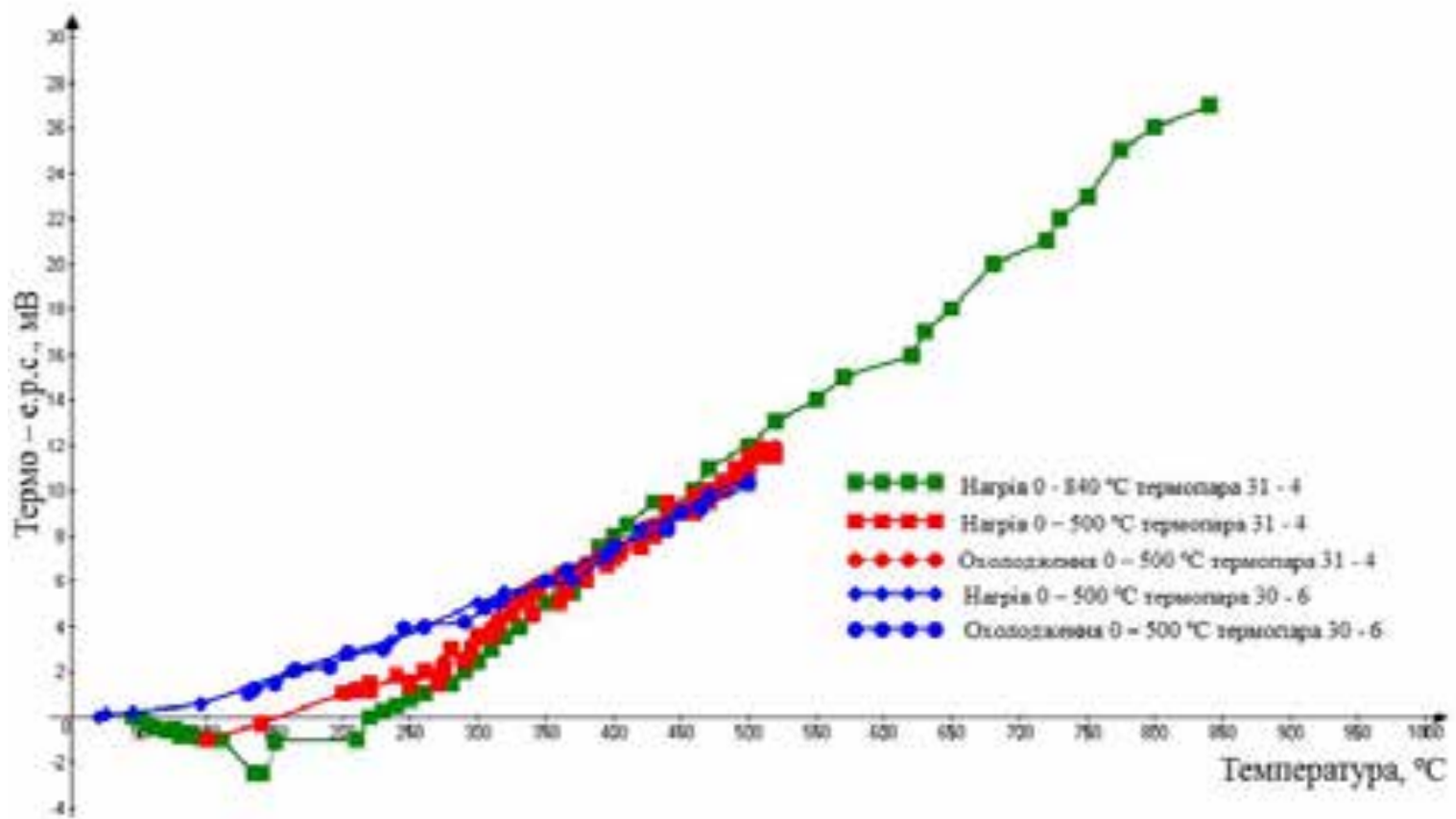

Рис. 4. Порівняння термо-е.p.c. термопар WC-SIALON/сажа-SIALON та TiB 2 SIALON/ сажа-SIALON (термопари 31-4 та 30-6 табл. 1)

Виходячи 3 кривої нагрів-охолодження функціонального елементу до температур $550 \div 950{ }^{\circ} \mathrm{C}$, видно, що процес нагрів-охолодження в межах похибки не впливає на величину термо-е.p.c. функціонального елементу. Викликає інтерес той факт, що при меншій концентрації WC, який відрізняється більшим значенням коефіцієнта термо-е.р.с. (15 об. \% WC проти 30 об. \% $\mathrm{TiB}_{2}$ ) в області температур $500{ }^{\circ} \mathrm{C}$, результуюча термо-е.p.c. складом гілки A WC-SIALON вища, ніж у функціонального пристрою зі складом $\mathrm{TiB}_{2}$ SIALON. Проте при температурах нижче $400{ }^{\circ} \mathrm{C}$ функціональні перетворювачі виконані 3 використанням $\mathrm{TiB}_{2}$-SIALON мають позитивний температурний коефіцієнт термо-е.p.c., тоді як матеріали 3 WC-SIALON в діапазоні температур до $250{ }^{\circ} \mathrm{C}-$ негативний або близький до нуля. Це говорить про те, що в контакті WC-SIALON/cажа-SIALON при температурах до $250{ }^{\circ} \mathrm{C}$ відбувається термокомпенсація знаку термо-е.р.с., а не його сумування. Тільки при температурі вище $250{ }^{\circ} \mathrm{C}$ відбувається сумування значень термое.p.c. обох гілок функціонального елементу.

Для перевірки гіпотези про виникнення можливої термокомпенсації на контакті бінарних композитів різного складу ми порівняли величину термо-е.р.с. для матеріалів 3 приблизно однаковою величиною коефіцієнта термо-е.р.с. ( $\left.\mathrm{TiB}_{2}, \mathrm{TaN}\right)$, що відрізняються позитивними гілками (сажа та вуглецеве волокно). 


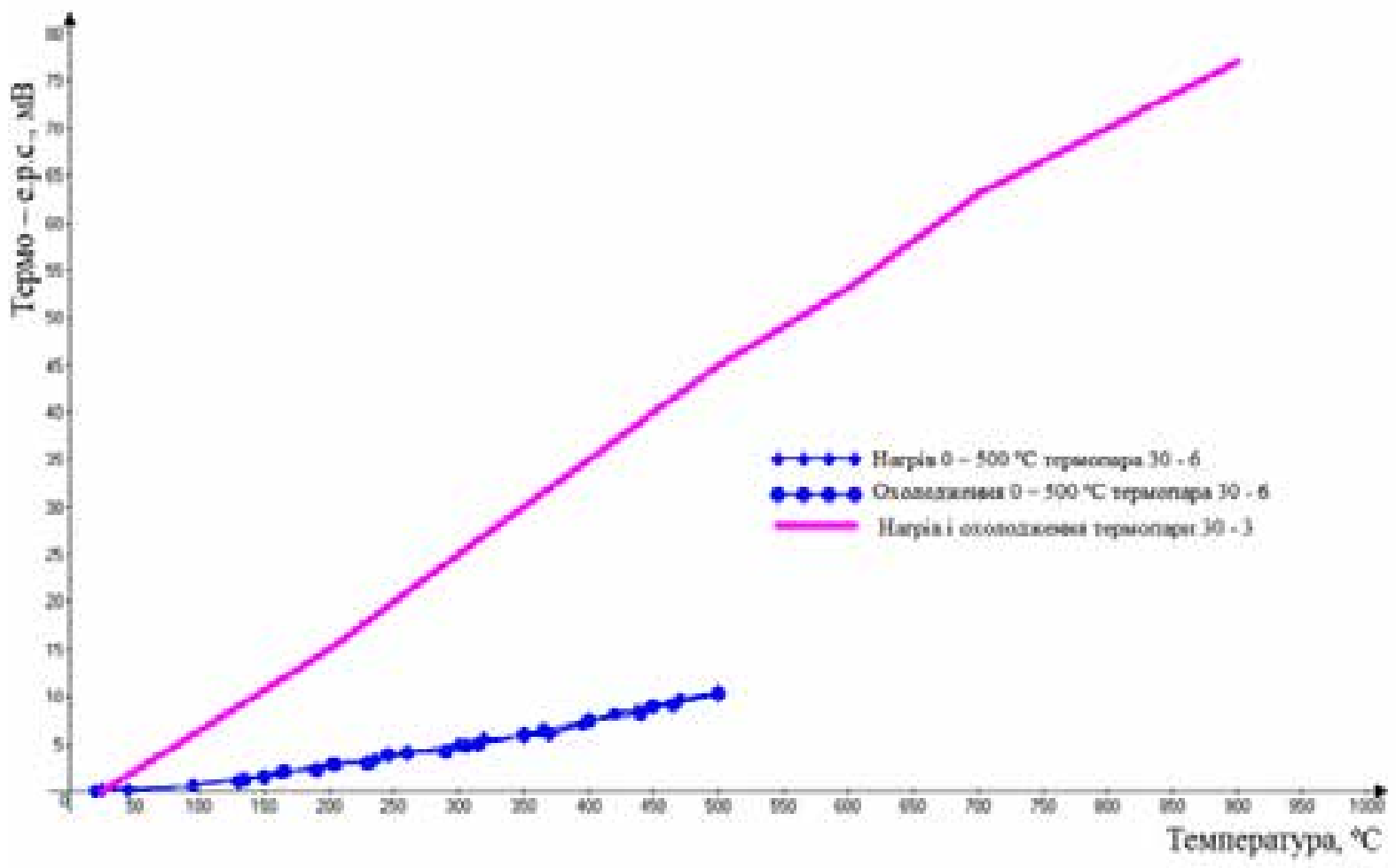

Рис. 5. Порівняння термо-е.p.c. термопар $\mathrm{TiB}_{2}-\mathrm{SIALON} /$ сажа-SIALON та TaNSIALON/вуглецеве волокно (термопари 30-6 та 30-3 табл. 1)

Як видно 3 рис. 5, величина термо-е.р.с. функціональних елементів 3 використанням композитів 3 домішками TaN при приблизно однаковій концентрації $\mathrm{i}$ температурі $800{ }^{\circ} \mathrm{C}$ майже в 3 рази перевищує значення термо-е.p.c. 3 добавкою $\mathrm{TiB}_{2}$, що говорить про суттєвий вклад саме вуглецю у вигляді волокна, реальна термо-е.р.с. якого приблизно в 3 раза більша за термо-е.р.с. порошкового композиту. Це говорить про те, що позитивний температурний коефіцієнт термо-е.р.с. в основному формується позитивною гілкою композиту з незначною можливістю до термокомпенсації.

Перевірку цієї гіпотези ми провели при застосуванні бікомпонентних систем 3 більшим значенням коефіцієнту термо-е.p.c. (ZrC-SIALON) і вищим позитивним значення коефіцієнту термо-е.p.c. (B 4 C-SIALON). Ми порівняли термопари TaN-SIALON/вуглецеве волокно та ZrC-SIALON/B ${ }_{4}$ C-SIALON (термопари під номерами 30-3 та 34-8 табл. 1) на рис. 6. Незважаючи на те, що негативні коефіцієнти термо-е.р.с. $\mathrm{TaN}$ i $\mathrm{ZrC}$ відрізняються приблизно в 5 разів - причому $\mathrm{ZrC}$ має більше значення коефіцієнту термо-е.p.c. результуючі значення коефіцієнтів термо-е.р.с. приладів співпадають між собою 3 точністю до похибки вимірювань (рис. 6). 


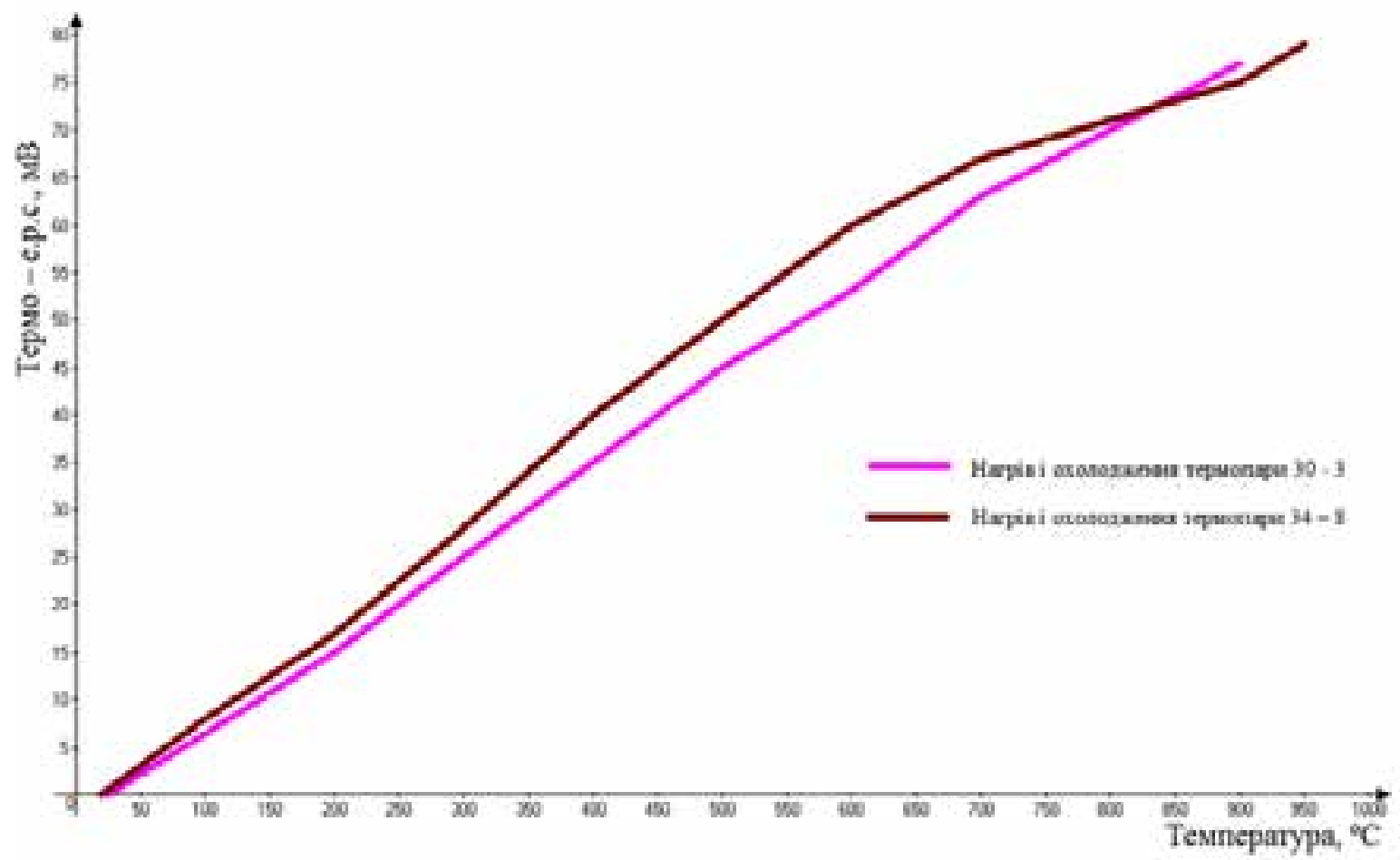

Рис. 6. Порівняння термо-е.p.c. термопар TaN-SIALON/вуглецеве волокно та ZrCSIALON/B ${ }_{4}$-SIALON (термопари 30-3 та 34-8 табл. 1)

Використання керамічних композитів ZrC-SIALON/B ${ }_{4} \mathrm{C}-\mathrm{SIALON}$ дає переваги у створенні високоефективних термоелектричних перетворювачів, в яких слабо відбуваються процеси термокомпенсації. Тому склад ZrC-SIALON/B 4 C-SIALON дає найбільшу величину термо-е.p.c. у порівнянні 3 величинами термо-е.p.c. металевих термопар при робочих темепартурах до $2500{ }^{\circ} \mathrm{C}$ (рис. 7).

У діапазоні температур від $900{ }^{\circ} \mathrm{C}$ до $2500{ }^{\circ} \mathrm{C}$ спостерігається лінійна залежність термо-е.p.c. від температури. При температурі $1750{ }^{\circ} \mathrm{C}$ коефіцієнт термо-е.p.c. перетворювачів на основі безкисневих сполук у 10 разів вищий за коефіцієнт термо-е.р.с. системи родій-іридій і в 4 рази вищий від коефіцієнту термо-е.р.с. термопари платинаплатинородій. При цьому керамічні термопари стійкі до різноманітних газових середовищ (окислювальних, відновлювальних, нейтральних), розплавлених металів, солей, шлаків.

Виходячи $з$ наведеного вище, подальше вивчення інерційності термоелектричних перетворювачів та повторюваності їх значень у порівнянні 3 величиною термо-е.р.с. металевих термопар проводились для найефективніших композицій $\mathrm{TiB}_{2}$-SIALON/сажаSIALON та ZrC-SIALON/B 4 C-SIALON (термопари під номерами 30-6 та 34-8, таблиця 1). 


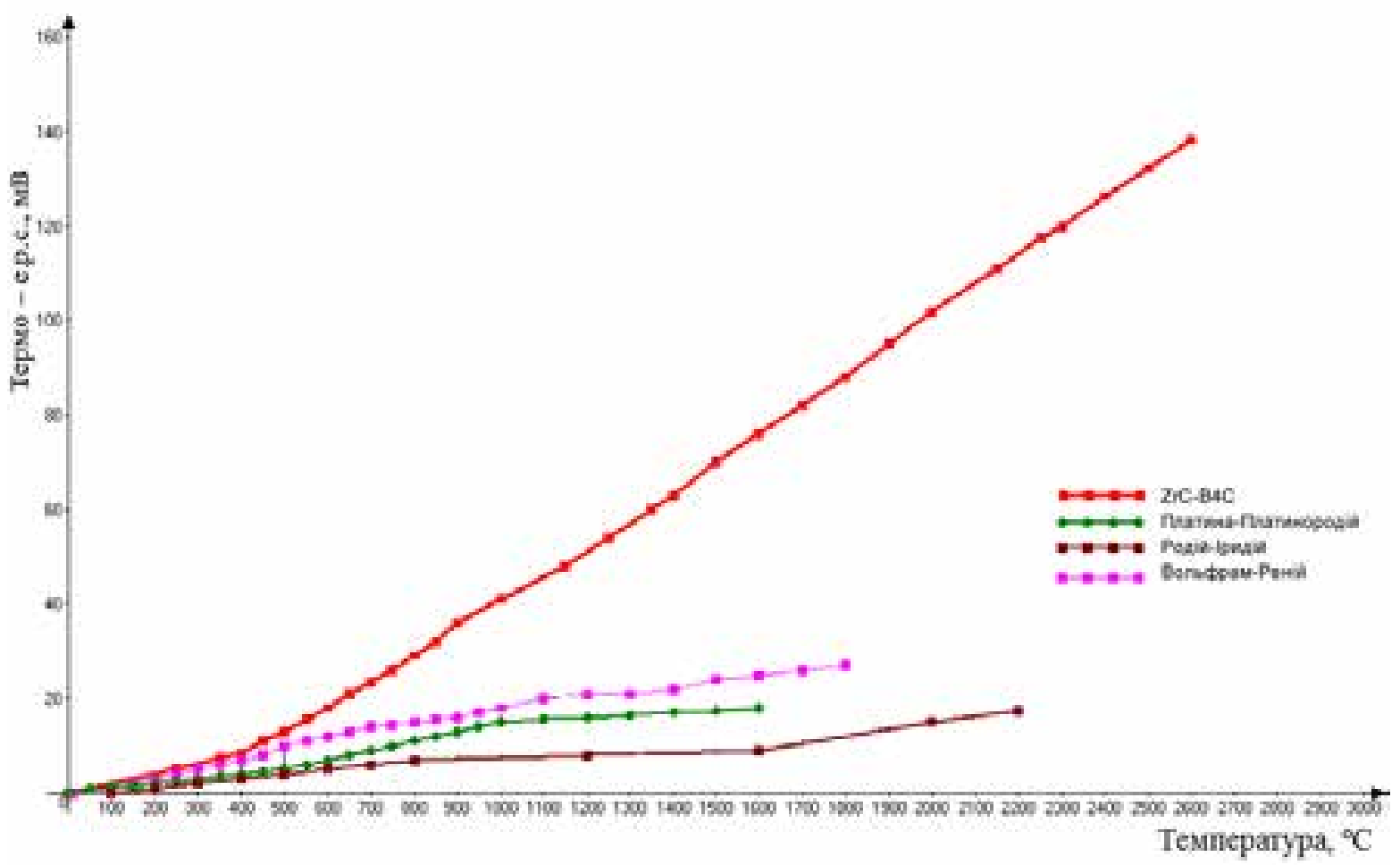

Рис. 7. Порівняння термопари ZrC-SIALON/B ${ }_{4} \mathrm{C}-\mathrm{SIALON}$ (34-8 у таблиці 1) 3 найбільш поширеними металевими термопарами

При дослідженні термопари ZrC-SIALON/B 4 C-SIALON (34-8, таблиця 1) у діапазоні температур $20-1300{ }^{\circ} \mathrm{C}$ спостерігалась дуже хороша відтворюваність сигналу, однак в діапазоні температур 400 - $600{ }^{\circ} \mathrm{C}$ була зафіксована генерація термоелектричної напруги з імпульсами високої частоти, а сама величина сигналу була приблизно у 5 разів вищою за сигнал від термопари $\mathrm{TiB}_{2}$-SIALON/сажа-SIALON (30-6, таблиця 1), яка досліджувалася другою.

Інерційність термопари ZrC-SIALON/B 4 C-SIALON (34-8, таблиця 1) була меншою у порівнянні з термопарою $\mathrm{TiB}_{2}$-SIALON/сажа-SIALON (30-6 0, таблиця 1), термопара показала високу повторюваність результатів вимірювання для 3-х різних циклів нагрівохолодження. 


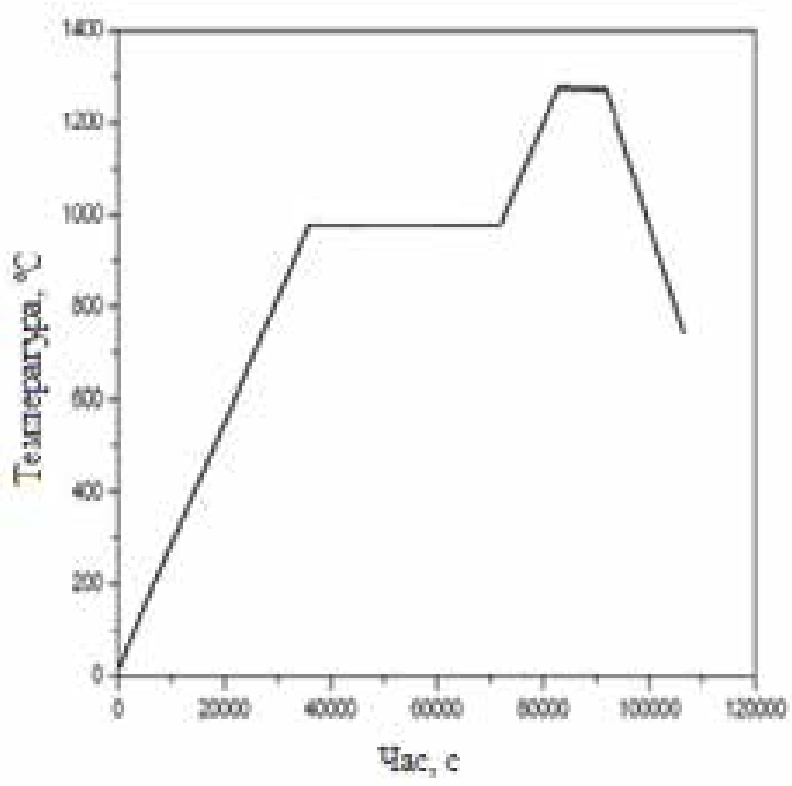

a

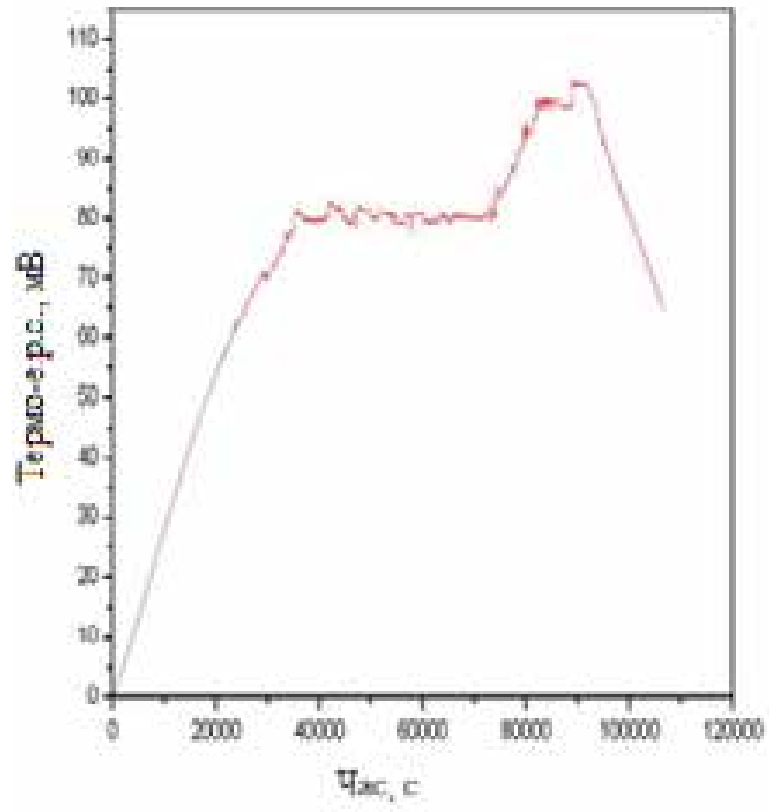

6

Профілі вимірюваної температури: а, в - стандартною термопарою;

б, г - керамічною термопарою 34-8

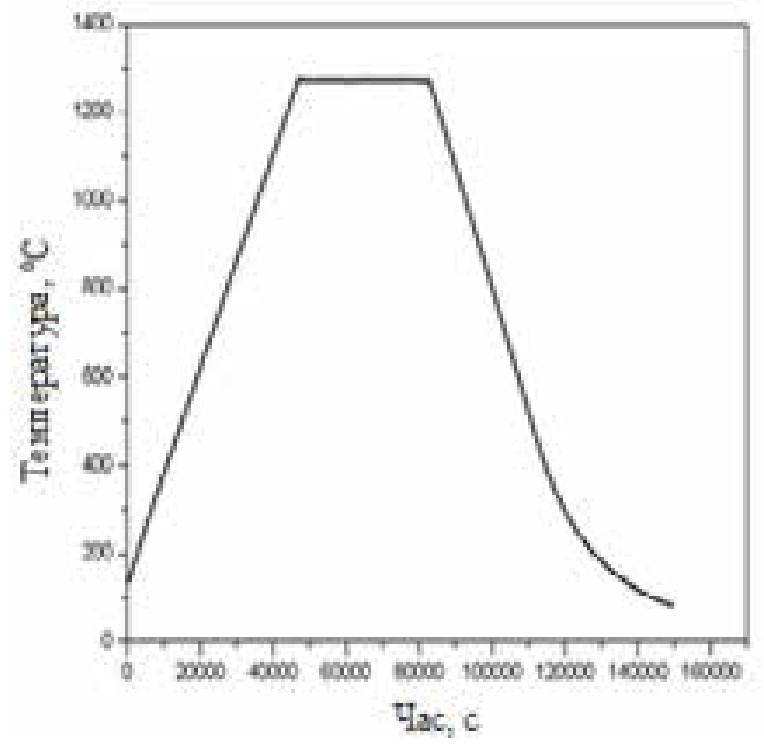

B

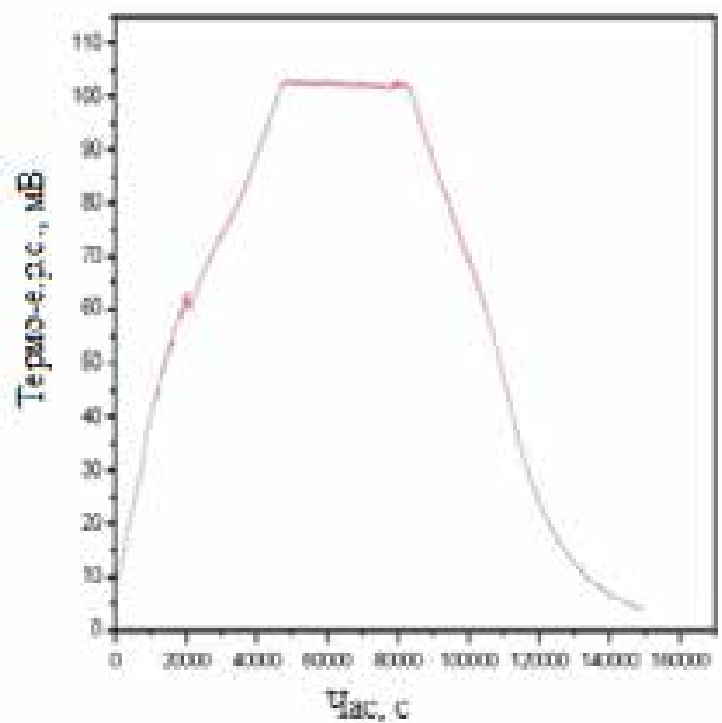

$\Gamma$

Рис. 8. Термоелектричний сигнал від еталонної термопари, платиноплатинородієвої (а, в), шарувато-радієнтної термопари ZrC-SIALON/B 4 C-SIALON (34-8, таблиця 1) (б, г) в залежності від часу роботи печі 


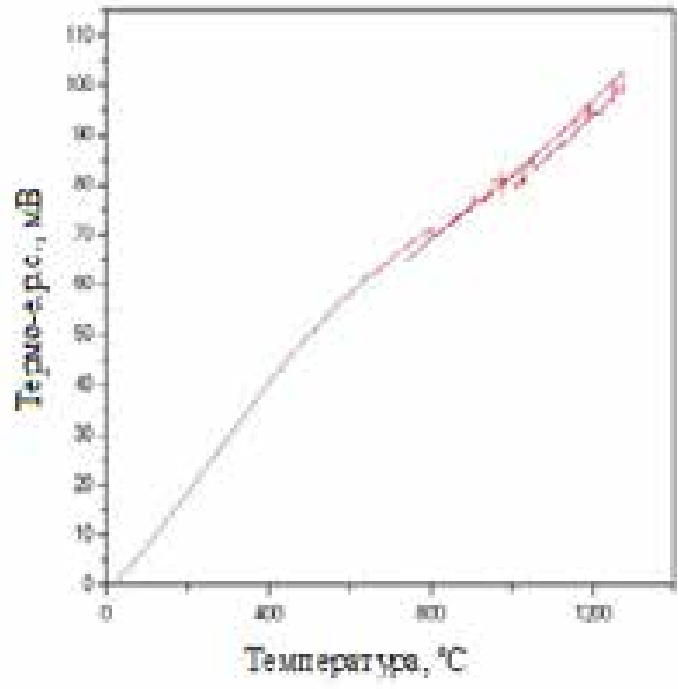

a

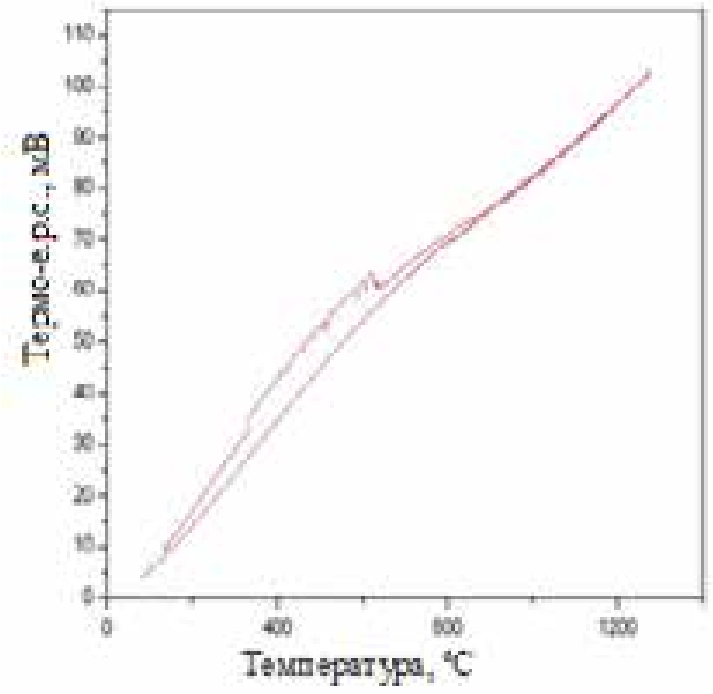

б

Рис. 9. Показники шарувато-градієнтної термопари ZrC-SIALON/B 4 C-SIALON (348, таблиця 1) при нагріві, при охолодженні печі: а - для низької, б - для високої швидкості нагріву печі

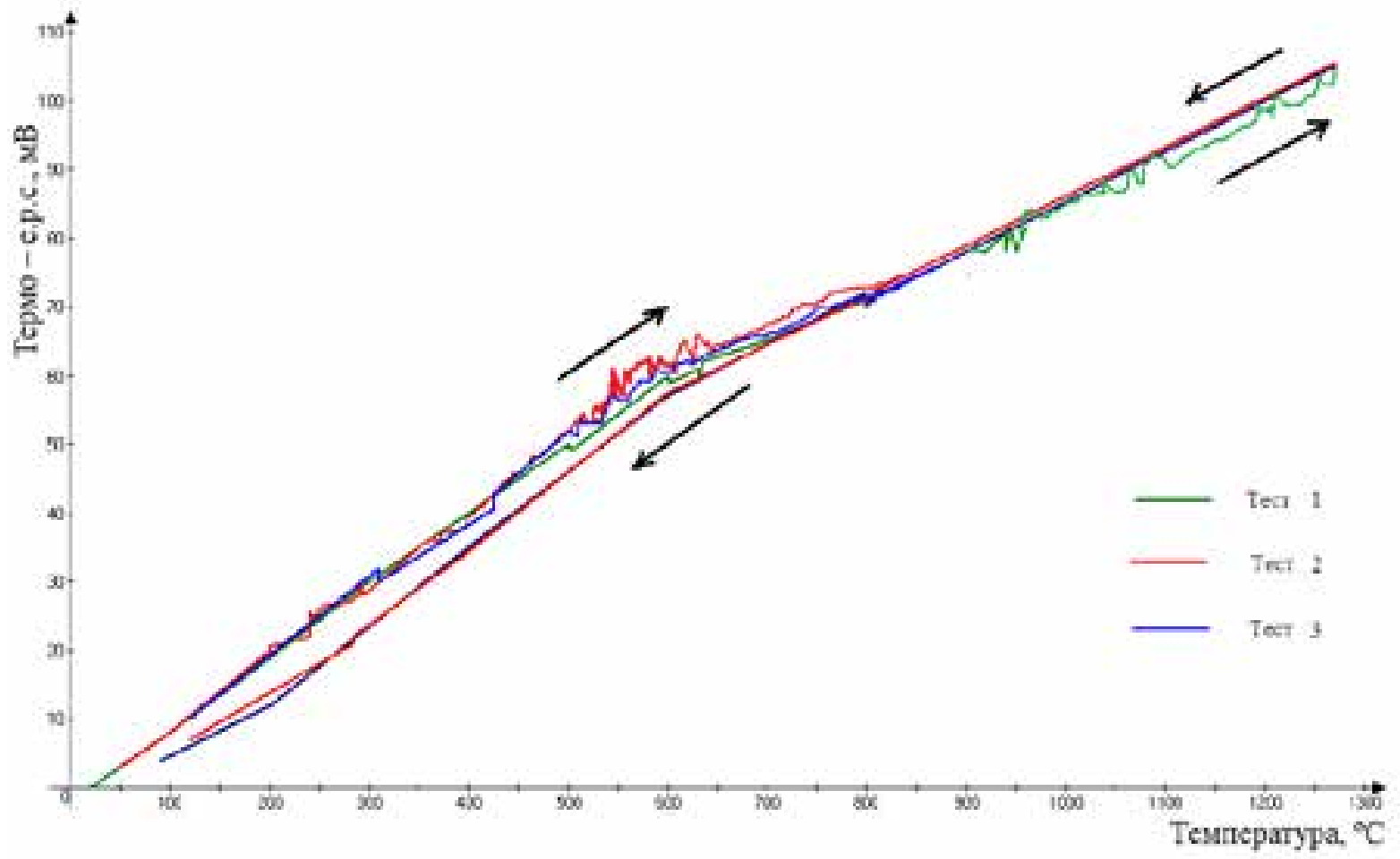

Рис. 10. Термоелектричний сигнал шарувато-градієнтної термопари $\mathrm{ZrC}$ SIALON/B 4 C-SIALON (34-8, таблиця 1) при 3-х різних циклах нагрів-охолодження

На рис. 11 показано порівняння термоелектричного сигналу еталонної термопари та композиції TiB2-SIALON/сажа-SIALON (30-6, таблиця 1). 


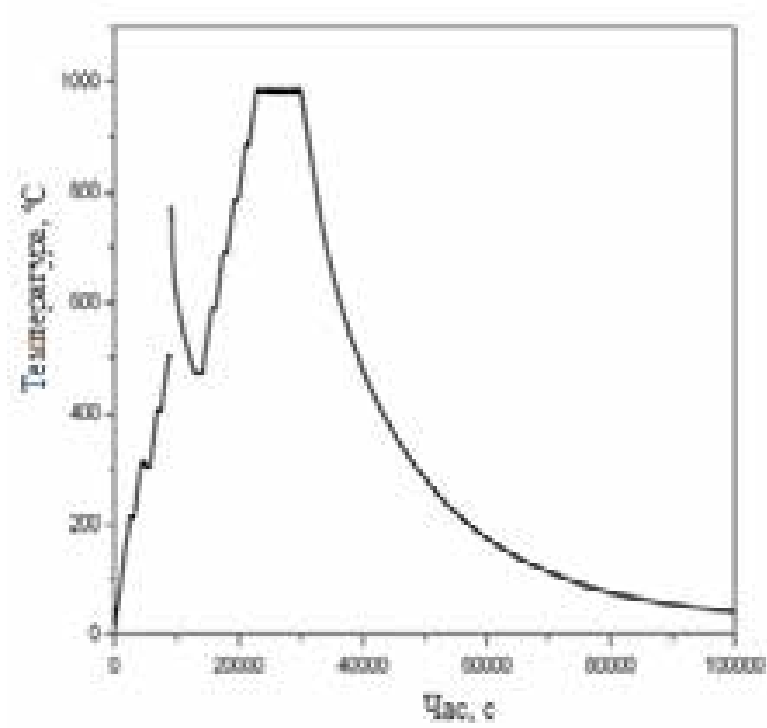

a

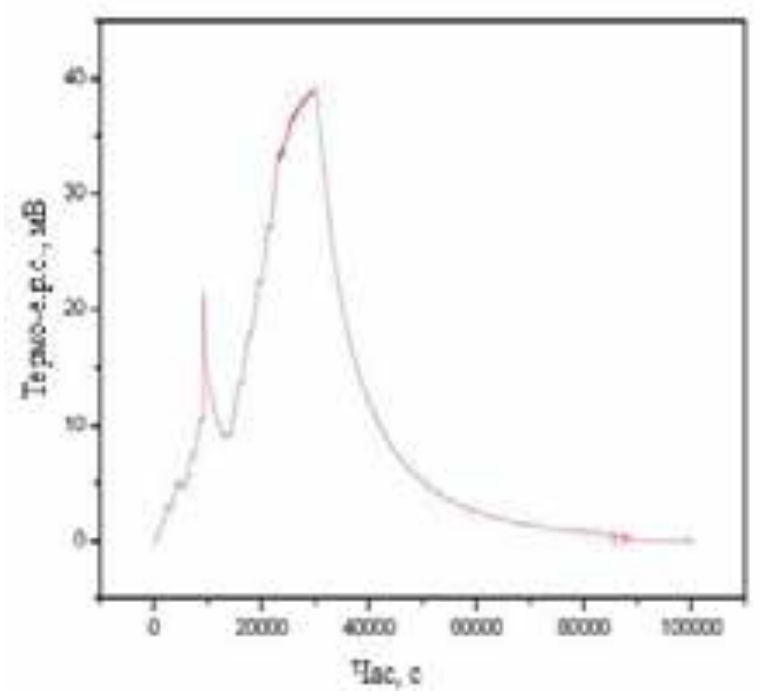

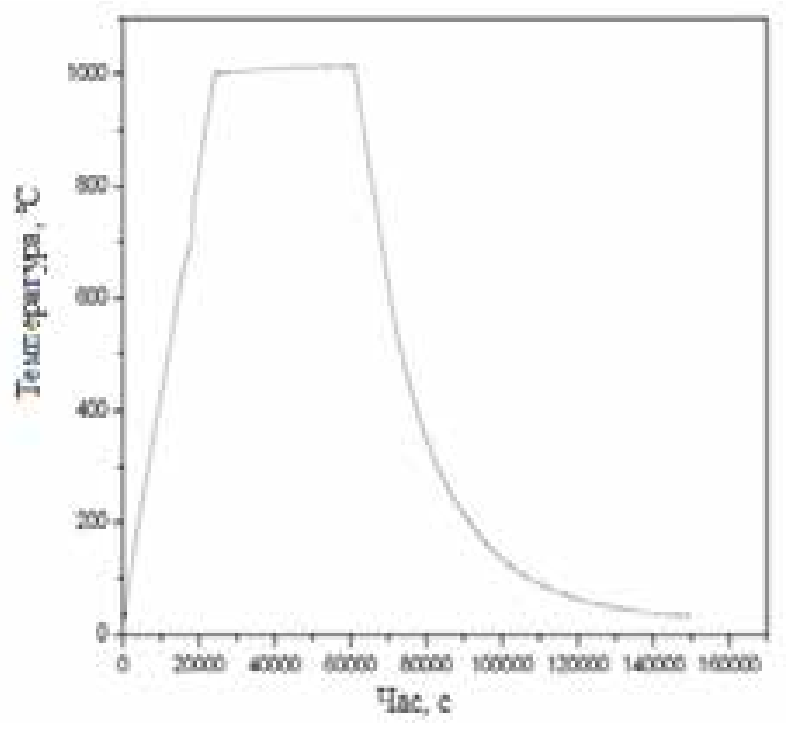

6

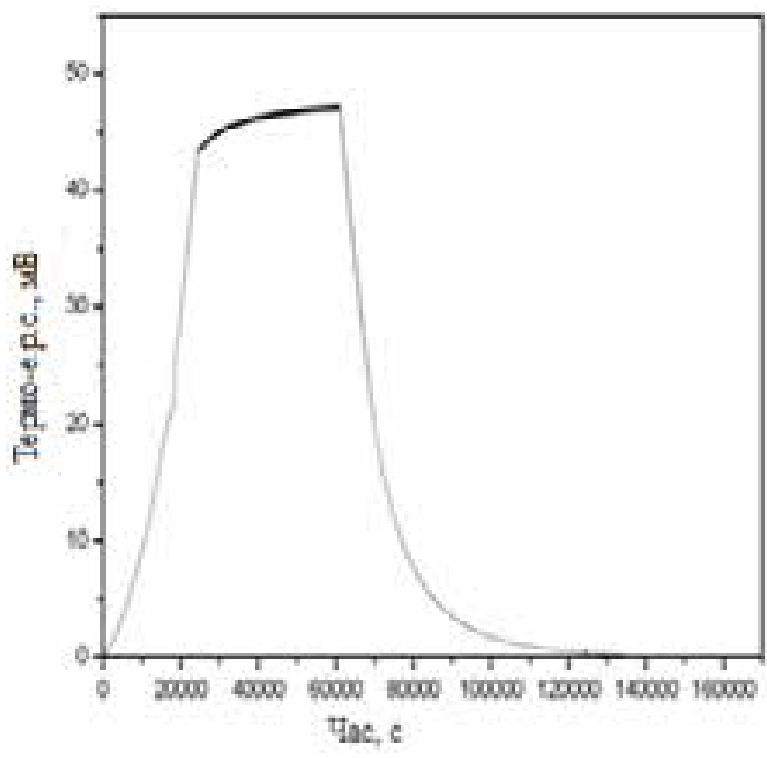

$\Gamma$

Профілі вимірюваної температури: а, б - стандартною термопарою;

в, г - керамічною термопарою

Рис. 11. Термоелектричний сигнал від еталонної термопари, платиноплатинородієвої (a, б) та шарувато-градієнтної термопари TiB 2 -SIALON/caжа-SIALON (30-6, таблиця 1) (в, г) в залежності від часу роботи печі 


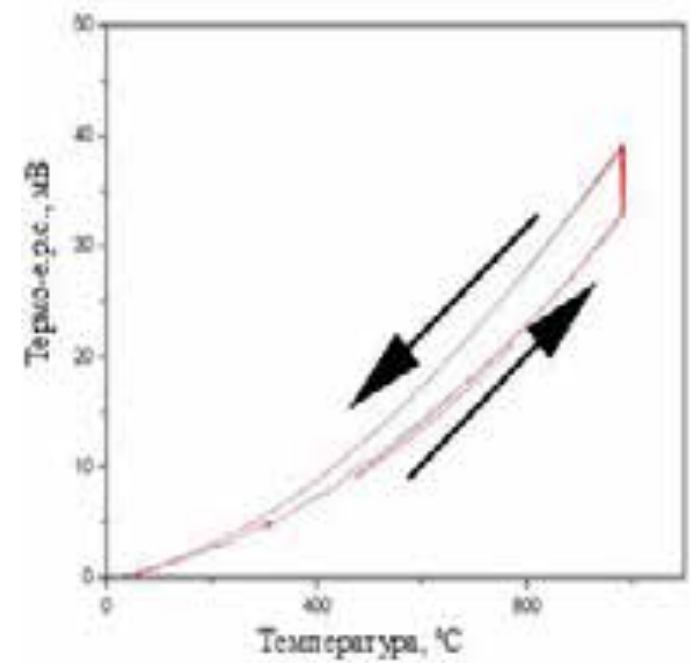

a

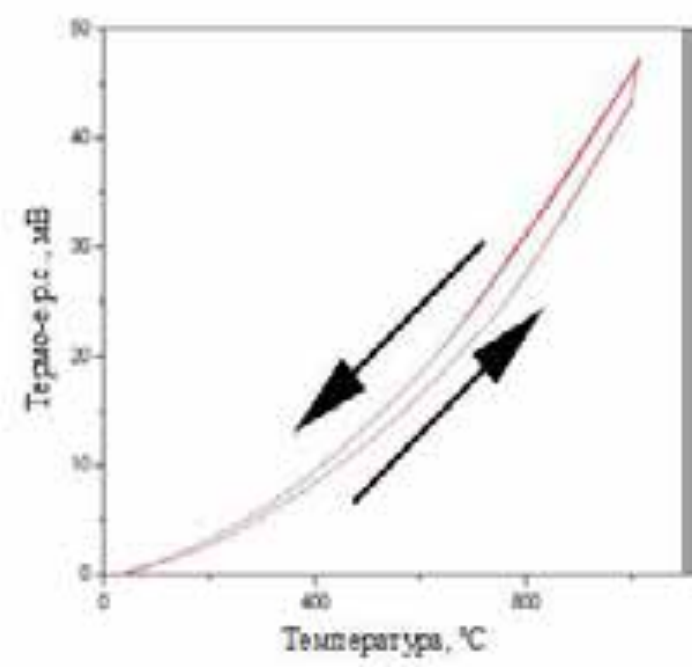

6

a - низька швидкість нагріву печі, б - висока швидкість нагріву печі

Рис. 12. Показники шарувато-градієнтної термопари $\mathrm{TiB}_{2}$-SIALON/сажа-

SIALON (30-6 табл. 1) при нагріванні (стрілка праворуч) та при охолодженні (стрілка ліворуч) печі

У ході експерименту ми встановили, що шарувато-градієнтна термопара точно відслідковує стан печі, однак в установленому режимі температури інерційність термопари складає близько 2-х хвилин. Як видно з рисунку, термопара не відреагувала на різке підвищення температури $3500{ }^{\circ} \mathrm{C}$ до $800{ }^{\circ} \mathrm{C}$.

Сигнал від термопари $\mathrm{TiB}_{2}$-SIALON/сажа-SIALON (30-6, таблиця 1) при iï охолодженні завжди набагато вищий від сигналу термопари при іiї нагріві, що пов’язано зі значною теплоємністю і великими габаритами виробу.

На рис. 13 показані результати вимірювання термо-е.p.c. термопари $\mathrm{TiB}_{2}-$ SIALON/сажа-SIALON (30-6, таблиця 1) в маслі і на повітрі. Як видно з рисунка, різниці у повторюваності результатів у маслі та на повітрі немає, але у маслі вище значення термоe.p.c. Це пов'язано з тим, що на повітрі охолодження відбувається повільніше, тому величина термо-е.p.c. має менше значення. 


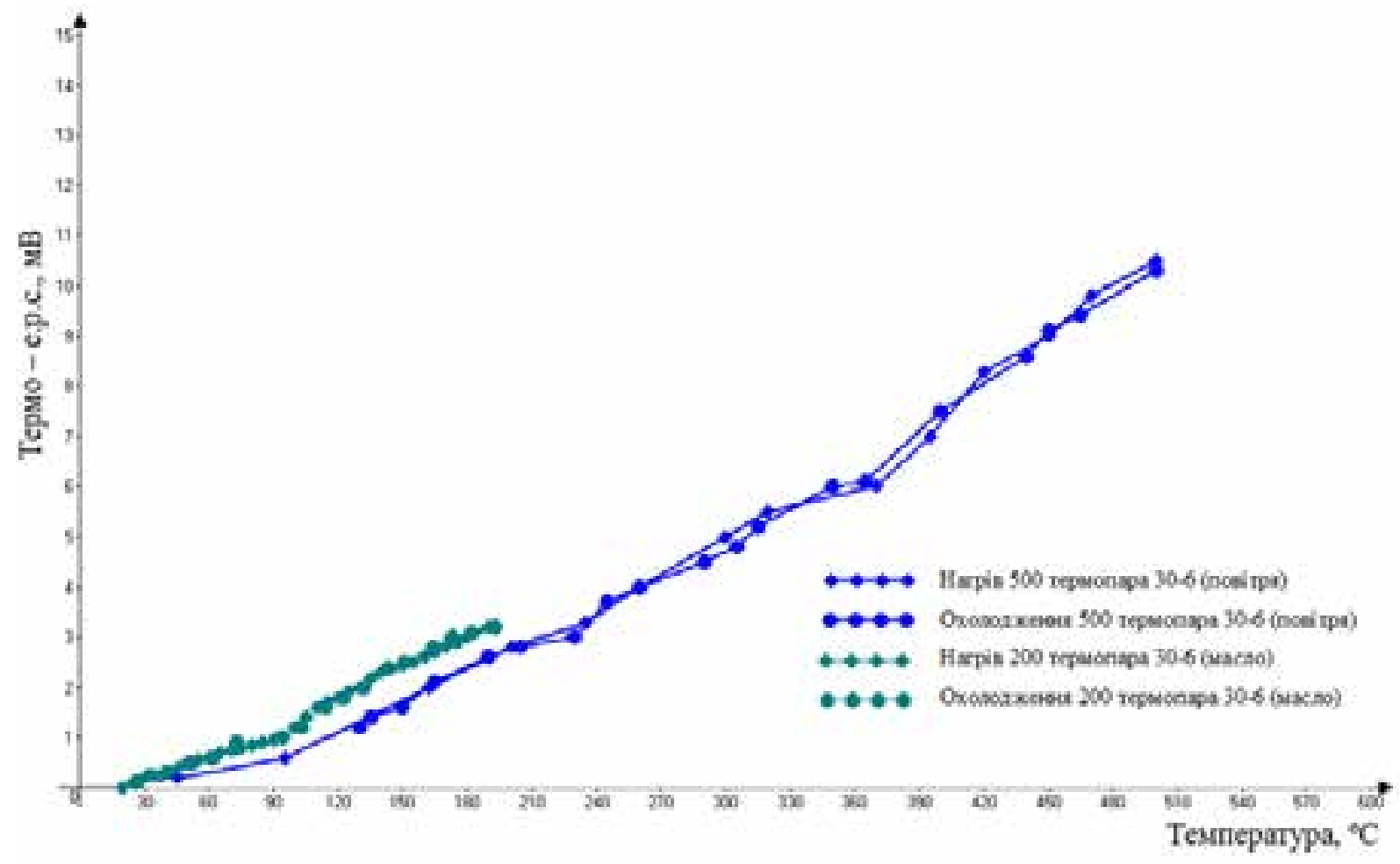

Рис. 13. Дослідження шарувато-градієнтної термопари $\mathrm{TiB}_{2}-\mathrm{SIALON} /$ сажа-SIALON (30-6 таблиця 1): 1 - в маслі, 2 - на повітрі

На рис. 14 показані результати вимірювання термо-е.р.c. термопари $\mathrm{TiB}_{2}-$ SIALON/сажа-SIALON (30-6, таблиця 1) для 3-х різних циклів нагрів-охолодження. Як видно $з$ рисунка, термопара TiB $_{2}$-SIALON/сажа-SIALON (30-6, таблиця 1) показала непоганий результат повторюваності результатів вимірювання.

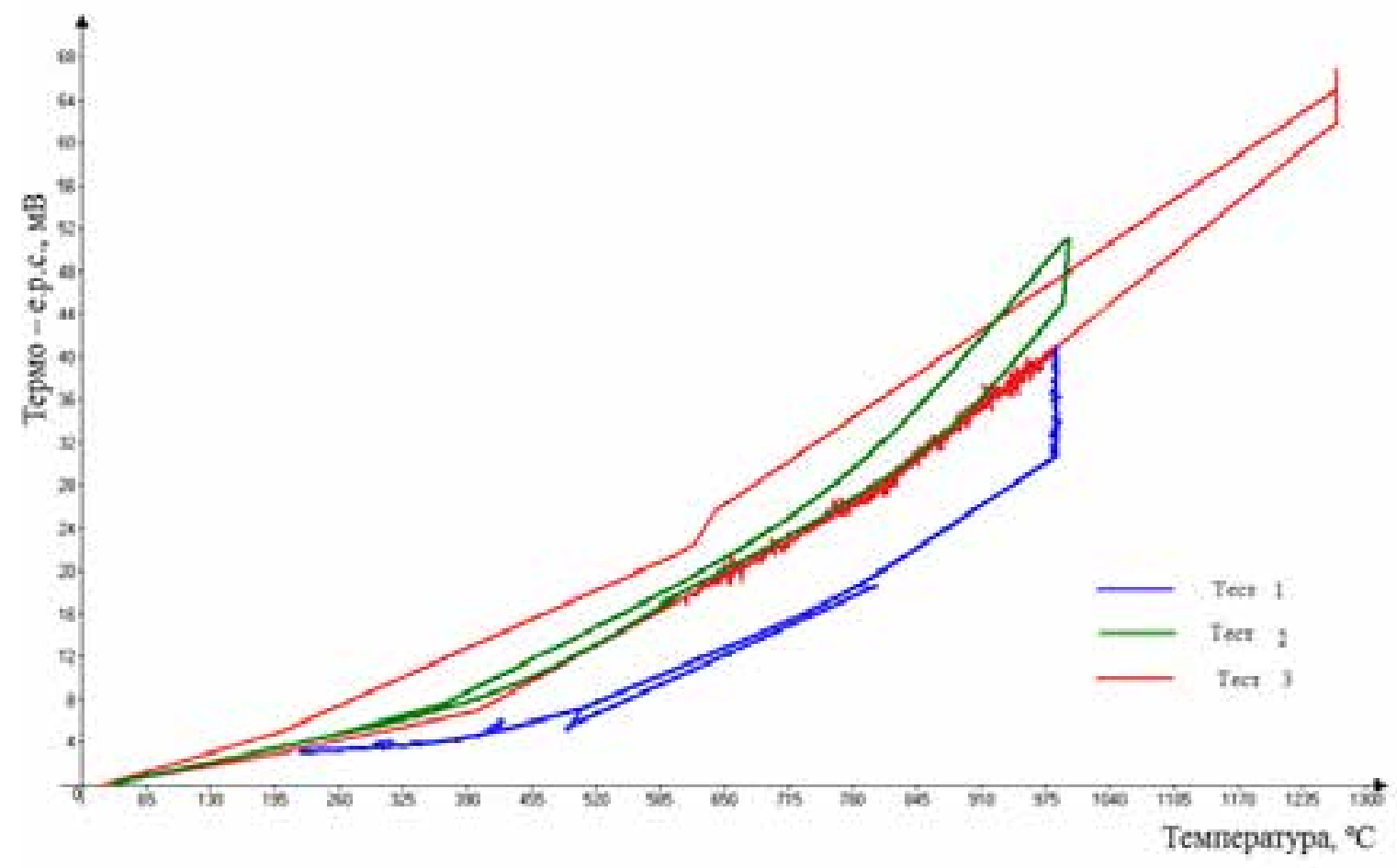




\section{Висновки}

1. При дослідженні композитних матеріалів вперше встановлено ефект термокомпенсації, що проявляється у тому, що матеріали WC-SIALON/сажа-SIALON проявляють в діапазоні температур до $250{ }^{\circ} \mathrm{C}$ від'ємне значення термо-е.p.c. за рахунок значної величини від'ємного значення домішки з негативним значенням коефіцієнту термо-е.р.с. При використанні композитів з меншою величиною негативного значення коефіцієнта термо-е.р.с. цей ефект має менше значення.

2. Вперше показано, що використання керамічних композитів ZrC-SIALON/B ${ }_{4} \mathrm{C}$ SIALON дає переваги у створенні високоефективних термоелектричних перетворювачів, в якому слабо відбуваються процеси термокомпенсації. Тому склад $\operatorname{ZrC~(11~об.~\% )-~}$ SIALON/B 4 C (40 об. \%)-SIALON дає найбільшу величину термо-е.p.c. у порівнянні 3 величинами термо-е.р.с. металевих термопар при робочих темепартурах до $2500{ }^{\circ} \mathrm{C}$.

3. Встановлено, що у діапазоні температур від $900{ }^{\circ} \mathrm{C}$ до $2500{ }^{\circ} \mathrm{C}$ спостерігається лінійна залежність термо-е.р.с. від температури . При температурі $1750{ }^{\circ} \mathrm{C}$ коефіцієнт термо-е.р.с. перетворювачів на основі безкисневих сполук у 10 разів вищий за коефіцієнт термо-е.р.с. системи родій-іридій і в 4 рази вищий від коефіцієнту термо-е.р.с. термопари платина-платинородій. При цьому керамічні термопари стійкі до різноманітних газових середовищ (окислювальних, відновлювальних, нейтральних), розплавлених металів, солей, шлаків.

4. Відмічено, що до недоліків керамічних термопар слід віднести велику інерційність, яка проявляється у тому, що термопари не відчувають пікових змін температури.

\section{Перелік посилань}

1. Самсонов Г.В., Кислый П.С. Высокотемпературные неметаллические термопары и наконечники. К.: «Наукова думка», 1965. - 180 с.

2. Rowe DM. CRC handbook of thermoelectrics. CRC; 1995.

3. Heremans JP, Jovovic V, Toberer ES, Saramat A, Kurosaki K, Charoenphakdee A, et al. Enhancement of thermoelectric efficiency in $\mathrm{PbTe}$ by distortion of the electronic density of states. Science2008;321(5888):554-7.

4. Wunderlich W, Ohta S, Ohta H, Koumoto K. Effective mass and thermoelectric properties of SrTiO3-based naturalsuperlatticesevaluatedbyab-initiocalcu- lations. In:Proceedings of the $24^{\text {th }}$ international conference on thermo-electrics, ICT2005; 2005. 
5. Wunderlich W, Ohta S, Ohta H, Koumoto K. Effective mass and thermoelectric properties of SrTiO3-based natural superlattices evaluated by ab-initio calculations. In: Proceedings of the 24th international conference on thermoelectrics, ICT2005;2005.

6. Петровский В.Я., Скороход В.В. Физические принципы и технологические аспекты получения градиентных композитов на основе бескислородной керамики. - Порошковая металлургия, № 3/4. - 1999. - С. 3 - 16.

7. Pat. No 94917644.0-2211 Europ., MKI H05B 3/14. Petrowski W. Keramisches Heizelement sowie Verfahren zur Herstellung eines solchen Heizelements. Опубл. 09.02.1995. - 9 c.

8. Pietrowskij W. Formowanie folii ceramicznych dla wykonania gradijentowego kompozytu zawierajacego O`-Sialon // Polski biuletyn ceramiczny, Ceramica. - 1997. - Nr16 (54). - P. 249 258.

9. Скал А.С. Критическое поведение термоэдс бинарных композитных материалов // ЖЭТФ. - 1985.88, вып. 2. - С. 516 - 521.

10. Самсонов Г. В. Тугоплавкие соединения, М.: Металлургиздат, 1963. - 265 с.

11. Самсонов Г. В. и др., «Изв. АН СССР, ОТН, сер. «Металлургия и топливо», 1961, №1.

12. Попов В. В., Гордеев С. К., Гречинская А. В., Данишевский А. М. Электрические и термоэлектрические свойства нанопористого углерода // Физика твердого тела, 2002, том 44, вып. 4.

13. Парфеньева Л. С., Смирнов Б. И., Смирнов И. А., Wlosewicz D., Misiorek H., Sulkowski Cz, Jezowski A., de Arellano-Lopez A. R., Martinez-Fernandez J.. Теплоемкость и коэффициент термоэдс биоуглеродной матрицы дерева сапели // Физика твердого тела, 2009, том 51, вып. 11.

14. Лабенский А. В., Кириленко Е. В., Курка В. А., Петровский В. Я. Влияние технологических факторов на термоэдс бинарных систем на основе $\mathrm{SiC}$ и композитов Si3N4-B4C // Керамика: наука и жизнь, №2(12). - 2011. - С. 63 - 74.

15. Цыгода В. В., Петровский В. Я. Влияние фрактальной размерности перколяционных кластеров на проводимость активных слоев керамических термопар // Керамика: наука и жизнь, №2(20). - 2013. - С. 12 - 20.

16. Волков А. И., Жарский И. М. Большой химический справочник. «Современная школа», 2005. - 607 с. 